\title{
TOTAL AND ORGANIC PHOSPHORUS IN CHILEAN VOLCANIC SOILS
}

\section{FOSFORO TOTAL Y FOSFORO ORGANICO EN SUELOS VOLCÁNICOS DE CHILE}

\author{
F. Borie ${ }^{1} \&$ R. Rubio
}

\begin{abstract}
This paper reviews the literature related to total and organic $\mathrm{P}(\mathrm{Po})$ levels present in both agricultural and forest soils from southern Chile. Different reports have demonstrated the high contents of total $\mathrm{P}(\mathrm{Pt})$ found in agricultural soils $\left(1,000-3,000 \mathrm{mg} \mathrm{kg}^{-1}\right)$ even in unfertilized soils. In most soils Po represents more than 50\% of Pt, mainly as inositol penta- and hexaphosphates linked to Fe and/or Al. Lipid-P has been found in very small quantities suggesting very fast cycling. When phosphate fertilizers are applied to these soils, the bulk of $\mathrm{P}$ is accumulated as macromolecular-P complexes closely associated with soil organic matter. Close relationships have been found between organic $\mathrm{C}$ and Po and between Po and $\mathrm{P}$ associated with humic acids (HA$\mathrm{P})$. When applying Hedley's chemical fractionation procedure to these soils some significant $\mathrm{P}$ fractions or pools of high lability are obtained suggesting a potential plant availability of some forms of accumulated $\mathrm{P}$, which can be manipulated by agricultural management. On the other hand, Pt in forest soils has been found in smaller quantities than in agricultural soils but Po also represents more than $50 \%$ of total P. The higher levels of labile $\mathrm{P}$ found in forest soils in comparison to agricultural ones together to higher $\mathrm{C} / \mathrm{Po}$ ratios are suggesting a faster $\mathrm{P}$ cycling in forest ecosystems.
\end{abstract}

KEYwords: Agricultural and forest soils, organic phosphorus, $\mathrm{P}$ availability, total phosphorus, volcanic soils. ${ }^{1}$ Universidad de La Frontera.Casilla 54-D, Temuco, Chile.
E-mail:fborie@ufro.cl

\section{RESUMEN}

Se realizó una revisión de la literatura relacionada con los niveles de $\mathrm{P}$ encontrados en suelos agrícolas y forestales del sur de Chile. Diferentes reportes señalan el alto contenido de $\mathrm{P}$ total $(\mathrm{Pt})$ en suelos agrícolas (1.000-3.000 mg kg-1) incluyendo suelos no fertilizados. En la mayor parte de los suelos el $\mathrm{P}$ orgánico (Po) constituye más del $50 \%$, asociado muy íntimamente a la materia orgánica, principalmente a ácidos húmicos. Los inositol penta- y hexafosfatos asociados a $\mathrm{Fe}$ y $\mathrm{Al}$ constituyen la mayor parte de este tipo de P. El P lipídico constituye tan sólo pequeñas cantidades sugiriendo una rápido ciclado. La acumulación del $\mathrm{P}$ en los suelos producto de la fertilización se produce mayoritariamente a través de la formación de complejos macromoleculares con la materia orgánica. Cuando se aplica a estos suelos el fraccionamiento químico de Hedley se encuentran fracciones de diferente labilidad, lo que sugiere que un adecuado manejo de estos suelos puede inducir a un aumento en la disponibilidad de P. Los suelos forestales, en cambio, poseen menor cantidad de $\mathrm{P}$ aunque el Po también supera el 50\% del Pt. Los mayores contenidos de formas lábiles de este elemento y una relación C/Po mayor señalan un ciclado más rápido del $\mathrm{P}$ en estos ecosistemas boscosos.

Palabras claves: Disponibilidad de P, fósforo orgánico, fósforo total, suelos volcánicos.

\section{INTRODUCTION}

Volcanic ash-derived soils have great importance in the economies of many countries especially in Asia, Africa and America. In Chile, volcanic soils support the bulk of agricultural and forestry production, covering more than $5.3 \times 10^{6}$ hectares and representing nearly $50-60 \%$ of the country's ar- 
able land (Besoaín 1985). The two main orders found in the south of the country are Andisols and Ultisols. In spite of many advantageous edaphic and climatic characteristics, these soils have other properties which can constraint plant growth. These include high Padsorption capacity with a concomitant low $\mathrm{P}$ availability, high levels of soil organic matter (SOM) with a variable degree of humification and, sometimes, high acidity levels with the appearance of $\mathrm{Al}, \mathrm{Mn}$ and $\mathrm{H}^{+}$ phytotoxicities (Borie \& Rubio 1999).

The clay fraction of volcanic soils contains large amounts of allophane, an amorphous aluminum silicate, together with allophane-like secondary minerals, and $\mathrm{Fe}$ and $\mathrm{Al}$ oxides. The dominance of actinomycetes and fungi (Zunino et al. 1982a) in the microbial communities of volcanic soils tends to make them highly reactive. These characteristics and interactions create a highly reactive soil environment, especially in relation to $\mathrm{P}$ adsorption. This is reflected in the following biological properties of these soils, which can help to understand the complexity of overall Pcycle in such habitats: (a) strong stabilization of indigenous organic matter and organic compounds when they are added to the soils (Zunino et al. 1982b); (b) high rates of microbial synthesis of humic- type macromolecules (Zunino et al. 1982c) and (c) high enzymatic activities including urease (Borie \& Fuentealba 1982), phenoloxidase (Peirano et al. 1992), and acid phosphatase (Borie et al. 1996).

In general, when $\mathrm{P}$ is applied to soils, often as much as $90 \%$ is not taken up by crops in the first year, being retained by soil colloidal surfaces in insoluble or fixed forms (Stevenson \& Cole 1999). A portion of the residual $\mathrm{P}$ may be acquired and used by subse- quent crops, but further additions of fertilizers are often required to maintain high crop yields and farmers are compelled to apply yearly high doses of phosphate. Continuous applications of $\mathrm{P}$ in amounts exceeding crop acquisition will inevitably result in an accumulation of $\mathrm{P}$ in the soil. Therefore, $\mathrm{P}$ content of almost cultivated and fertilized soils increases over the years and the extent of such accumulation will depend on the fertilizer application rate, years of application, the adsorptive capacity of soil matrix surfaces as well as on the microbial activity, especially microorganisms involved in P cycling.

In this context, fixation of phosphate in allophanic soils is perhaps one of the major factors limiting their agronomic use. The mechanisms involved in such fixation processes have been widely investigated using short-term equilibrium procedures. The conclusion has been reached that phosphate retention in these soils is mainly due to the ability of the amorphous aluminium silicate clay to strongly adsorb the phosphate mainly by ligand-exchange mechanisms (Parfitt 1980). It is also generally accepted that a repeated application of inorganic $\mathrm{P}$ in acid organic soils results in an agronomic $\mathrm{P}$ build-up and that this form of phosphorus participates somehow in the P-cycle and may contribute to the pool of available P (Anderson 1975; Vance et al., 1996). Chilean volcanic soils are no exception and $\mathrm{P}$ fertilizers are accumulated in their upper horizons. Chemical fractionation for studying the lability and the nature of these accumulated $\mathrm{P}$ forms has been applied to different types of volcanic soils (Escudey et al. 2001; Pinochet et al. 2001). Results of these studies, and their possibilities for increasing the availabilities of such $\mathrm{P}$ forms will be discussed further on.

TABle I. Total P (Pt) and organic P $\left(\mathrm{P}_{\mathrm{o}}\right)$ from 15 cultivated and uncultivated (native grasslands) Chilean volcanic soils

\begin{tabular}{|c|c|c|c|c|}
\hline & \multicolumn{2}{|c|}{ Cultivated } & \multicolumn{2}{|c|}{ Uncultivated } \\
\hline & Range & Mean & Range & Mean \\
\hline Total P (mg kg-1) & $1,422-4,011$ & 2,582 & $1,150-3,243$ & 1,854 \\
\hline Po (mg kg-1) & $870-3,197$ & 1,618 & $650-2,375$ & 1,147 \\
\hline Available-P (mg kg-1) & $3-165$ & 45 & $3-41$ & 10 \\
\hline $\mathrm{Po} / \mathrm{Pt} \times 100$ & $42-80$ & 56 & $48-79$ & 62 \\
\hline Humic-P (\%Po) & $59-95$ & 61 & $43-81$ & 53 \\
\hline Fulvic-P (\%Po) & $5-41$ & 39 & $19-57$ & 47 \\
\hline Organic-C (\%) & $4.6-9.8$ & 6.6 & $4.6-9.6$ & 5.9 \\
\hline $\mathrm{C} / \mathrm{Po}$ & $31-53$ & 41 & $41-71$ & 51 \\
\hline
\end{tabular}

From Borie \& Barea (1983) and Borie \& Zunino (1983) 
P in Chilean volcanic soils: Borie, E. \& R. Rubio

ORGANIC PHOSPHORUS IN AGRICULTURAL VOLCANIC SOILS

In the early 1980's field samples of fertilized and unfertilized volcanic soils representing the main soil series from southern Chile were screened for Pt and Po (Table I; Borie \& Barea 1983; Borie \& Zunino 1983). Total $P$ was determined by soil oxidation with sodium hypobromite (Dick \& Tabatabai 1977). Po was determined as the difference between Pt and inorganic P (Stewart \& Oades 1972). Po was also fractionated and analyzed as being associated with humic acids (HA-P) or with fulvic acids (FA$\mathrm{P})$, the latter representing the $\mathrm{P}$ forms with a higher potential lability for being mineralized or degraded by soil microorganisms. On the other hand, humic-P, with higher molecular weights represents a more recalcitrant pool, hardly degraded either by microbial or enzymatic activity and, consequently, with lower $P$ availability.

A wide range of $\mathrm{P}$ contents was found in the studied soils (Borie \& Zunino 1983). However, as expected, cultivated soils presented higher amounts of both total and available $P$ than uncultivated soils (Table I). In general, Po represented more than $50 \%$ of Pt in all analyzed soils even in uncultivated grassland soils. Table I also shows that organic $\mathrm{C}$ contents were higher in cultivated than in uncultivated soils. The difference between $\mathrm{Pt}$ from cultivated and uncultivated soils represents a $\mathrm{P}$ accumulation produced by agronomic soil management, especially by phosphate fertilization. All the data in Table I suggest that inorganic $\mathrm{P}$ applied as fertilizer is being accumulated in the soils in organic-P forms or intimately associated with SOM (Borie \& Zunino 1983).

It is known that in some acid soils with high organic matter content, $\mathrm{P}$ - accumulation is produced through the formation of organic compounds of high molecular weight suggesting the formation of humate-Al-phosphate complexes (Vance et al. 1996). In addition, C/P ratios in organic matter of mineral soils oscillate around 100 depending on soil genesis, texture and environmental conditions (Barber 1995). C/P ratios in these organic temperate soils ranged from 31 to 53 for cultivated and 41-71 for uncultivated soils, which support the idea that $P$ build-up is highly related to organic matter accumulation. In the analysis of these soil samples, no clear relationship between organic $\mathrm{C}$ and Po was observed.

Borie et al. (1989) have analyzed samples of

TABLE II. Po, humic-P (HA-P), fulvic-P (FA-P), inositol-P (INP) and C/Po ratio reported in volcanic soils under grasslands.

\begin{tabular}{|c|c|c|c|c|c|c|c|c|c|}
\hline \multirow[t]{2}{*}{ Soil } & \multicolumn{7}{|c|}{$\begin{array}{c}\mathrm{P} \\
\left(\mathrm{mg} \mathrm{kg}^{-1}\right)\end{array}$} & \multirow{2}{*}{$\begin{array}{l}\text { Po } \\
(\% \mathrm{Pt})\end{array}$} & \multirow[t]{2}{*}{$\mathrm{C} / \mathrm{Po}$} \\
\hline & Total & Po & HA-P & $(\% \mathrm{Po})$ & FA-P & INP & $(\% \mathrm{Po})$ & & \\
\hline 1 & 2,348 & 1,007 & 637 & 63 & 370 & 499 & 49 & 43 & 75 \\
\hline 2 & 1,925 & 1,052 & 638 & 61 & 414 & 705 & 67 & 55 & 73 \\
\hline $3^{*}$ & 1,849 & 1,083 & 721 & 66 & 362 & 709 & 65 & 59 & 75 \\
\hline $4^{*}$ & 1,107 & 654 & 333 & 51 & 321 & 415 & 63 & 59 & 87 \\
\hline 5 & 2,697 & 1,302 & 867 & 66 & 435 & 612 & 47 & 49 & 71 \\
\hline 6 & 2,327 & 1,492 & 1,041 & 68 & 478 & 987 & 66 & 64 & 67 \\
\hline 7 & 2,476 & 1,450 & 965 & 66 & 485 & 612 & 42 & 59 & 48 \\
\hline 8 & 3,121 & 1,310 & 841 & 64 & 469 & 750 & 57 & 42 & 61 \\
\hline 9 & 2,362 & 1,208 & 793 & 65 & 415 & 778 & 64 & 51 & 66 \\
\hline Mean & 2,246 & 1,173 & 760 & 63 & 417 & 674 & 58 & 53 & 69 \\
\hline
\end{tabular}

\footnotetext{
* Typic Vitrandepts. The other soils are Typic Distrandepts . From Borie \& Barea (1983) and Borie et al.(1989).
} 
representative volcanic soils under grasslands from the $9^{\text {th }}$ and $10^{\text {th }}$ regions of southern Chile in order to further explore the nature of P (Table II). Phosphorus was found to be associated with organic macromolecules (Po) which represented a high proportion of $\mathrm{Pt}$, ranging from 42 to $64 \%$ with a mean of $53 \%$. There was a significant correlation between organic $\mathrm{C}$ and $\mathrm{Po}(\mathrm{r}=0.73, \mathrm{p}<0.05)$, suggesting a high affinity between $\mathrm{P}$ and humus and $\mathrm{C} / \mathrm{Po}$ ranged from 48 to 87 with a mean of 69 . The so-called "humus P" represented by $\mathrm{P}$ associated to humic (HA$\mathrm{P})$ and fulvic acids (FA-P) ranged from 51 to $68 \%$ with a mean of $63 \%$ for HA-P and from 32 to $49 \%$, and a mean of $37 \%$ for FA-P, respectively (Table II). In addition, Po and HA-P presented a strong relationship $(\mathrm{r}=0.99, \mathrm{P}<0.5)$ supporting the hypothesis postulated by Borie \& Zunino (1983) that $\mathrm{P}$ accumulation in Chilean volcanic soils is occurring through the formation of humic-P complexes. These results agree well with those reported by Baker (1977), who found $71 \%$ of Po associated with humic acids in New Zealand soils from two chronosequences. It is well known that New Zealand soils are similar to Chilean volcanic soils in terms of genesis and climatic conditions.

Inositolphosphates (INP) usually represent > $50 \%$ of soil organic $\mathrm{P}$ compounds and are extracted from soils with a rather drastic chemical procedure involving $\mathrm{NaOH}$ and temperature (Irving \& Cosgrove 1982). These severe extracting conditions could produce significant hydrolytic effects in INP and the true values could be higher than those quantified (Borie 1981). In spite of such constraints, INP levels found in the sampled soils ranged from 42 to $67 \%$ with a mean of $58 \%$ suggesting that the bulk of the Po is associated with humic acids (HA-P; Table II). Further studies carried out in the same soils using dialysis and gel permeation for estimating molecular weight of such macromolecules have confirmed that the greater proportion of $\mathrm{P}$ is included in the organic structure of the soil matrix and intimately associated with humic-like compounds and inositol esters (Borie et al. 1989). Data obtained after HA-P combustion and subsequent metal analysis allow us to conclude that INPs in these soils are intimately associated with $\mathrm{Fe}$ and Al, especially with the former (Borie et al., unpublished data).

The total quantity of phospholipids in agricultural soils is small, usually less than $5 \mathrm{mg} \mathrm{P} \mathrm{kg}^{-1}$, or from 0.6 to $3.0 \%$ of the soil organic $\mathrm{P}$ (Dalal 1977) being undoubtedly of microbial origin. In spite of its low $\mathrm{P}$ content, soil lipid $\mathrm{P}$ may represent an important intermediate compound for plant and microbial nutrition and the low levels could indicate a $\mathrm{P}$ substrate of rapid cycling. In a study of lipidic-P in volcanic soils, Borie \& Barea (1985) found very small quantities with a range from 0.06 to $0.72 \%$, and no significant differences between fertilized or unfertilized soils were observed.

In agricultural soils all forms of $\mathrm{P}$ are potentially available to plants. The availability degree will depend on the solubility and structure of chemical forms, on the susceptibility to microbial attack, as well as on the soil-root environment. Moreover, Po necessarily must be previously mineralized before plant absorption. It is well known that the inputs of nucleic acids and phospholipids to soils are likely to be much greater than INP; however, they are broken down more quickly and $\mathrm{P}$ coming from these compounds will be quickly cycled, so that quantities found in soils are generally low (Dalal 1977; Stevenson \& Cole 1999).

Nuclear magnetic resonance spectroscopy ${ }^{31} \mathrm{P}$ NMR is a relatively new approach for characterizing soil P (Stevenson \& Col 1999). In recent years, Escudey et al. $(1997 ; 2001)$ and Briceño (2001) and Briceño et al. (2003) have further explored the nature of Po in Chilean volcanic soils using this technique. They sampled ten volcanic soils (two Ultisols and eight Andisols) for studying the differences in quantities and nature of Po from the two soil orders and also for obtaining qualitative and quantitative estimates of the $\mathrm{P}$ forms in soil alkaline extracts. Results of such screening showed Po ranging from 32 to $75 \%$, being higher for Andisols with a greater proportion of $\mathrm{P}$ associated with humic acids (HAP) than for Ultisols. A close relationship between HA-P and Po was observed, reinforcing the earlier findings reported by Borie et al. (1989). The largest proportion of the Po detected by NMR in extracts from those volcanic soils has been monoester$\mathrm{P}$, which includes inositol phosphates ranging from 17-64\% (Escudey et al. 2001). Being soil INPs derived from plants, animal and microbial residues, they may accumulate as organic-P derived from fertilizer application for increasing pasture production (Condron et al. 1985). INP is strongly held by chemisorption on Fe and Al components of soil particle surfaces and is protected from dephospho- 
rilation reactions, which could explain its persistence in soils (Robinson et al. 1998) and its stability against microbial and enzymatic attack (Zhang et al. 1999).

Monoester-P found in higher amounts in Andisols (25-64\%) than in Ultisols (17-45\%), may be due to the higher levels of organic matter and humus-P complexes with $\mathrm{Fe}$ and $\mathrm{Al}$ that these soils contain. Diester-P was observed in low amounts in some Andisols and most frequently in the $0-15 \mathrm{~cm}$ depth range (Escudey et al. 2001). Major sources of diester-P in the soils include microbial-derived nucleic acids and phospholipids. Hinedi et al.(1988, 1989) have observed, by ${ }^{31} \mathrm{P}-\mathrm{NMR}$, that diester-P is hydrolyzed and mineralized faster than monoester$P$. These reactions may explain the relatively low amounts of diester-P observed previously in some Chilean volcanic soils (Bishop et al. 1994) in addition to the above-mentioned values for phospholipids found in some of this type of soils (Borie \& Barea 1985) when using the traditional method of lipid extraction (Bligh \& Dyer 1959).

\section{PHOSPHORUS FRACTIONATION AND BIOLOGICAL ACTIVITY}

Lability and availability of the forms of $\mathrm{P}$ in soils has come largely from chemical fractionation based on the ability of selective chemical reagents to solubilize discrete types of inorganic $\mathrm{P}$ compounds. Thus, the procedure of Chang \& Jackson (1957) has been used for more than 30 years. However, a major disadvantage of this fractionation scheme, and its subsequent modifications, is that some of the inorganic $\mathrm{P}$ is derived from the soil Po (Stevenson $\&$ Cole 1999). Borie (1981) reported 17 and 85\% of hydrolysis for Fe phytate and Al phytate, respectively, when $\mathrm{H}_{2} \mathrm{SO}_{4} 0.5 \mathrm{M}$ is applied to alkaline extracts for humic acid floculation as it is recommended by the original procedure.

More recently, Hedley et al. (1982) have introduced a sequential extraction procedure whereby soil $\mathrm{P}$ is separated into inorganic and organic fractions or pools that vary in their availability to plants. Essentially, a progression of stronger reagents is used, which is related to $\mathrm{P}$ bioavailability. Thus, biologically available $\mathrm{Pi}$ is removed first with anion exchange resin followed by a mild extractant $\left(\mathrm{NaHCO}_{3}\right)$ used to remove "labile" $\mathrm{Pi}$ and Po forms. At this step, inclusion of a chloroform treatment permits estimation of Po originating from lysis of microbial cells. Extraction with $\mathrm{NaOH}$ estimates Pi slightly adsorbed to Fe and Al minerals, which is supposed to be also labile. Stable $\mathrm{P}$ forms, such as highly insoluble inorganic and

TABLE III. Mean P fractions ( $\left.\mathrm{mg} \mathrm{kg}^{-1}\right)$ in two cultivated $(+\mathrm{P})$ and uncultivated $(-\mathrm{P})$ volcanic soils determined by the sequential extraction procedure of Hedley et al., (1982)

\begin{tabular}{|c|c|c|c|c|c|c|c|}
\hline \multirow{2}{*}{$\begin{array}{l}\text { SOIL } \\
\mathrm{P} \text { fraction }\end{array}$} & \multicolumn{4}{|c|}{ VILCUN } & \multicolumn{3}{|c|}{ OSORNO } \\
\hline & & $-\mathrm{P}$ & $+\mathrm{P}$ & $\Delta \mathrm{P}$ & $-\mathrm{P}$ & $+\mathrm{P}$ & $\Delta \mathrm{P}$ \\
\hline Labile P & $\mathrm{Pi}$ & 14 & 77 & 63 & 29 & 224 & 195 \\
\hline (NaHCO3) & Po & 13 & 19 & 6 & 34 & 85 & 51 \\
\hline Microbial $\mathrm{P}$ & $\mathrm{Pi}$ & 14 & 36 & 22 & 19 & 50 & 31 \\
\hline (NaHCO3/CHCl3) & Po & 21 & 25 & 4 & 32 & 59 & 27 \\
\hline Chemisorbed $\mathrm{P}$ & $\mathrm{Pi}$ & 527 & 811 & 284 & 503 & 589 & 85 \\
\hline$(\mathrm{NaOH})$ & Po & 943 & 1,436 & 493 & 110 & 2,161 & 1,061 \\
\hline Internal $\mathrm{P}$ & $\mathrm{Pi}$ & 151 & 196 & 45 & 57 & 82 & 25 \\
\hline (Ultrasonic $\mathrm{NaOH}$ ) & Po & 673 & 703 & 30 & 548 & 588 & 40 \\
\hline Ocluded P & $\mathrm{Pi}$ & 96 & 165 & 69 & 34 & 63 & 29 \\
\hline$(\mathrm{HCl})$ & Po & 172 & 217 & 45 & 26 & 41 & 15 \\
\hline \multirow{3}{*}{$\begin{array}{l}\text { Residual P } \\
\left(\mathrm{NaOBr}-\mathrm{t}^{\circ}\right)\end{array}$} & $\mathrm{Pi}$ & 665 & 839 & 174 & 1,033 & 1,280 & 247 \\
\hline & $\Sigma \mathrm{Pi}$ & 1,468 & 2,124 & 656 & 1,675 & 2,288 & 613 \\
\hline & $\Sigma$ Po & 1,822 & 2,427 & 605 & 1,780 & 2,894 & 1114 \\
\hline
\end{tabular}

From Borie et al., unpublished data. 
organic P compounds, are classified as recalcitrant with low possibilities of mobilization towards $P$ forms with higher lability, or of solubilization by root or microbial activity.

The fractionation procedure of Hedley et al. (1982) and the more recent adapted by Tiessen \& Moir (1993) have been used for assessing the complex dynamics of $\mathrm{P}$ in soils after soil management especially crop rotation and organic residue addition. When Hedley procedure was applied to two Andisols with different management practices but a similar organic C content (around 10\%), a different behavior was observed. The Vilcún soil was subjected to a normal crop rotation (oats-lupinewheat-ryegrass) and the Osorno soil was under heavily-fertilized pasture for ten years $\left(300 \mathrm{~kg} \mathrm{P}_{2} \mathrm{O}_{5}\right.$ $\left.\mathrm{ha}^{-1}\right)$. Pt of both soils increased with cultivation, and $\mathrm{P}$ accumulated by $\mathrm{P}$ fertilization was 45 and $62 \%$, for the Vilcún and Osorno soils, respectively (Table III). Results show that accumulated P corresponds mainly as inorganic forms in Vilcún soil and organic ones in the Osorno soil. Po accumulation was also different in both soils. Thus, whereas in the Vilcún soil Po was associated with fulvic acids (FA-P) which is thought to be moderately labile, in the Osorno soil it was associated to humic acids (HAP) with lower lability.

Soil management practices play a crucial role in P cycling. In this context, the effect of tillage and crop rotation on the shifting of $\mathrm{P}$ from fractions with different lability are at present being studied by our group in an Andisol (Vilcún soil). Thus, it has been recently reported that the addition of the equivalent of 3 ton $\mathrm{ha}^{-1}$ fresh vegetal residues to the Vilcún soil, with $4 \mathrm{mg} \mathrm{kg}^{-1}$ available-P, produced a major increase of the fraction of labile-P, suggesting increased mineralization Po rate (Borie et al. 2002).

The effect of tillage systems and crop rotation on lability of $\mathrm{P}$ fractions is also being studied in the same Vilcún soil. Results obtained suggest that, in general, no-tillage (NT) increases the levels of labile-Pi extracted with $\mathrm{NaHCO}_{3}$ in comparison with conventional tillage (CT). Pi extracted with $\mathrm{NaOH}$, also considered to be potentially labile, has been found in higher levels in NT than CT treatments suggesting a shifting from more recalcitrant $\mathrm{P}$ forms towards $\mathrm{P}$ forms with higher lability (Table IV).

\section{ORGANIC P IN FOREST SOILS}

A study of the distribution of $\mathrm{P}$ fractions according to their potential bioavailability was recently reported by Pinochet et al. ( 2001) in eight soils under native forest. Variation in the accumulation of $\mathrm{P}$ was evaluated over east-west soil transect of soils derived from volcanic ash deposits of different ages and metamorphic materials. All soils were located in the $10^{\text {th }}$ region of southern Chile, from the

TABLE IV. Phosphorus fractions obtained by extraction with $\mathrm{NaHCO}_{3}$ and $\mathrm{NaOH}$ according to the procedure of Hedley et al., (1982) in an Andisol with different crop rotations and under non tillage (NT) and conventional tillage (CT). (Borie et al., unpublished).

\begin{tabular}{|c|c|c|c|c|c|c|c|c|}
\hline \multirow[t]{3}{*}{ Crop rotation* } & \multicolumn{4}{|c|}{$\mathrm{NaHCO}_{3}-\mathrm{P}$} & \multicolumn{4}{|c|}{$\mathrm{NaOH}-\mathrm{P}$} \\
\hline & \multicolumn{2}{|c|}{ NT } & \multicolumn{2}{|c|}{$\mathrm{CT}$} & \multicolumn{2}{|c|}{ NT } & \multicolumn{2}{|c|}{$\mathrm{LC}$} \\
\hline & $\mathrm{Pi}$ & Po & $\mathrm{Pi}$ & Po & $\mathrm{Pi}$ & $\mathrm{Po}$ & $\mathrm{Pi}$ & $\mathrm{Po}$ \\
\hline $\mathrm{P}_{2}-\mathrm{O}$ & 33.2 & 46.6 & 30.9 & 26.9 & 747 & 1,552 & 510 & 1,426 \\
\hline$P_{1}-P_{2}$ & 29.1 & 31.6 & 27.7 & 34.0 & 850 & 1,434 & 532 & 1,133 \\
\hline $\mathrm{W}-\mathrm{P}_{1}$ & 35.8 & 26.5 & 23.7 & 50.9 & 617 & 995 & 422 & 1,184 \\
\hline$L-W$ & 46.5 & 31.3 & 29.6 & 31.2 & 826 & 1,200 & 544 & 1,192 \\
\hline $\mathrm{O}-\mathrm{L}$ & 38.6 & 52.2 & 25.3 & 32.5 & 418 & 1,134 & 513 & 1,325 \\
\hline Mean & 36.7 & 37.6 & 27.5 & 35.1 & 756 & 1,263 & 504 & 1,252 \\
\hline
\end{tabular}

$* \mathrm{P}_{2}$ : Pasture $2^{\text {nd }}$ year; $\mathrm{P}_{1}$ : Pasture $1^{\text {st }} ; \mathrm{W}$ : Wheat; L: Lupin; O: Oats 
P in Chilean volcanic soils: Borie, E. \& R. Rubio

TABLE V. Phosphorus fractions in forest soil samples of volcanic origin from a transect from the Andean mountains to the coast in southern Chile.

\begin{tabular}{lcrrrrrrrr}
\hline SoilSeries & \multirow{2}{*}{ Resin } & \multicolumn{2}{c}{$\mathrm{NaHCO}_{3}$} & \multicolumn{2}{c}{$\mathrm{NaOH}$} & \multicolumn{2}{c}{ Total P } & C/Po & $\begin{array}{c}\text { Labile } \\
(\% \mathrm{Pt})\end{array}$ \\
\hline Antillanca & 3.7 & 7.4 & 40.9 & 29.8 & 156.2 & 64 & 354 & 242 & 23 \\
Chauleufu & 5.4 & 8.6 & 38.6 & 42.1 & 242.8 & 72 & 456 & 315 & 21 \\
Puyehue & 6.4 & 10.4 & 65.0 & 94.1 & 483.5 & 69 & 961 & 233 & 18 \\
Huiño-Huiño & 6.3 & 9.2 & 56.9 & 91.9 & 544.3 & 78 & 882 & 205 & 19 \\
Osorno & 4.8 & 10.0 & 65.1 & 227.2 & 519.5 & 54 & 1,414 & 145 & 22 \\
Corte Alto & 1.4 & 8.1 & 41.1 & 190.9 & 403.6 & 53 & 1,010 & 150 & 24 \\
Cudico & 5.2 & 13.6 & 72.7 & 132.4 & 359.9 & 53 & 1,073 & 131 & 14 \\
Hueicoya & 7.0 & 12.0 & 59.5 & 188.9 & 290.6 & 59 & 737 & 208 & 23 \\
\hline
\end{tabular}

For classification and location of the above soils see Pinochet et al. (2001).

TABLE VI. Phosphorus fractions in soils $(0-10 \mathrm{~cm}$ depth) of one broadleaf and two coniferous forest watersheds in the Cordillera de Pichué, Chiloé, Chile.

\begin{tabular}{lcc}
\hline $\begin{array}{l}\text { Hedley-Tiessen } \\
\text { Fraction }\end{array}$ & \multicolumn{2}{c}{ Soil phosphorus concentration $\left(\mathrm{mg} \mathrm{kg}^{-1}\right)$} \\
\cline { 2 - 3 } & BROADLEAF & CONIFEROUS \\
\hline Resin P & $66.5 \pm 9.0$ & $96.3 \pm 11.3$ \\
NaHCO3 Pi & $15.2 \pm 1.5$ & $10.6 \pm 1.7$ \\
NaHCO3 Po & $69.2 \pm 6.2$ & $46.3 \pm 4.4$ \\
NaOH Pi & $26.8 \pm 4.5$ & $11.2 \pm 2.4$ \\
NaOH Po & $121 \pm 23.1$ & $89.7 \pm 7.4$ \\
Dilute acid Pi & $9.2 \pm 2.2$ & $3.1 \pm 0.7$ \\
Acid Pi & $37.2 \pm 3.9$ & $16.8 \pm 4.4$ \\
Acid Po & $34.8 \pm 5.3$ & $56.5 \pm 8.0$ \\
Residual & $36.2 \pm 2.4$ & $29.5 \pm 12.2$ \\
Total & $413 \pm 33$ & $357 \pm 25$ \\
Po $(\%$ of total P) & 54 & 54 \\
Labile P $(\%)$ & 43 & 46 \\
\hline
\end{tabular}

From Thomas et al. (1999)

Andean mountains (east) to the coast range (west) and were sampled at $0-20 \mathrm{~cm}$ depth. The soils showed a Pt content ranging from 354 to $1,414 \mathrm{mg}$ $\mathrm{kg}^{-1}$, depending on their evolution degree and genesis (Table V). In all the sampled soils the largest $\mathrm{P}$ content was in organic forms $(53-82 \%)$ and was higher for recent than more mature soils. The largest accumulation of Po was in the fraction extracted by $\mathrm{NaOH}$, which correlated well with total $\mathrm{C}$ content $(\mathrm{r}=0.748 ; \mathrm{p}<0.05)$. C/Po ratios ranged from 131 to 315, being higher for the soils close to the Andean mountains.

Another similar study, including chemical $\mathrm{P}$ fractionation, was carried out in three forest soils of the Cordillera Piuché, Chile (42³0' S) on Isla de Chiloé. This area has undergone minor inputs of ashes from Andean volcanoes and consequently non amorphous minerals and micavermiculite dominate in the clay fraction (Thomas et al. 1999). Although these soils are not 
classified as true volcanic soils we have included them here only for comparison with volcanic allophanic soils. In relation to the different $P$ forms found in these soils, the authors reported $\mathrm{Pt}$ ranging from 357 to $413 \mathrm{mg} \mathrm{kg}^{-1}$ with Po around 54\%, and labile $\mathrm{P}$ representing more than $43 \%$ in the three research sites studied (Table VI). The authors concluded that pools of labile P estimated to be available to plants are significantly larger than the annual demand for $\mathrm{P}$ in that setting.

\section{CONCLUSIONS}

In conclusion, a large proportion of $\mathrm{P}$ is found in organic $\mathrm{P}$ forms in both agricultural or Chilean forest soils derived from volcanic ashes. However, as most plants can only utilize $\mathrm{P}$ in inorganic form, the activity of phosphatase enzyme is crucial for hydrolyzing Po to inorganic form. $\mathrm{Pt}$ is higher in agricultural soils than in forest ecosystems. The lower quantities of $\mathrm{P}$ forms found in forest soils, together with their higher bioavailability, can be explained by the high fungal weathering of primary $\mathrm{P}$ minerals observed in forest soils, including the activity of ectomycorrhizal fungi (Landeweert et al. 2001). In addition, a recent study reported that roots of tree species showed higher phosphatase activity and organic acid excretion than those of maize, a typical crop species (George et al, 2002). This could explain the higher $\mathrm{P}$ cycling rate in forest soils in relation to agricultural systems. However, as $\mathrm{P}$ cycling in soils depend on several factors including soils genesis, climatic environment and plant activity, comparisons of agricultural and forest systems developed on similar sites should be an important priority for future work.

\section{ACKNOWLEDGMENTS}

This work was partially funded by FONDECYT Grant 1020306

\section{REFERENCES}

Anderson, G. 1975. Other organic phosphorus compounds. In: Soil components, organic components, vol. 1 (ed K.G. Gieseking), pp 305-333,
Springer Verlag. N.Y.

BAKer, R. T. 1977. Humic acid-associated organic phosphate. New Zealand Journal of Soil Science 20: 439-441.

BARber, S. A. 1995. Soil nutrient bioavailability: a mechanistic approach. $2^{\text {nd }}$ Edn. John Wiley \& Sons, New York, USA, 414 pp.

Besoain, E. 1985. Los suelos volcánicos . En: Suelos volcánicos de Chile, cap. 1 ( ed J. Tosso), pp 25-106. Instituto de Investigaciones Agropecuarias (INIA).

Bishop, M., A. C. Chang \& R. W. K. Lee. 1994. Enzymatic mineralization of organic phosphorus in a volcanic soil of Chile. Soil Science 157: 238-243.

Bligh, E.C \& W.J. Dyer. 1959. A rapid method of total lipid extraction and purification. Canadian Journal of Biochemistry and Physiology 37:911-917.

Borie, F. 1981. Caracterización de diversas fracciones del $\mathrm{P}$ en andosoles chilenos y significado de los microorganismos, con especial referencia a las micorrizas, en el aporte de dicho macronutriente a las plantas. Tesis Doctoral, Universidad de Granada, España.

Borie, F. \& R. Fuentealba. 1982. Bioquímica de suelos derivados de cenizas volcánicas II. Actividad ureásica. Agricultura Técnica 42: 135-142.

Borie, F. \& H. Zunino 1983. Organic matter-phosphorus associations as a sink in P-fixation processes on allophanic soils of Chile. Soil Biology and Biochemistry. 15: 599-603.

Borie, F. \& J. M. Barea. 1983. Fósforo orgánico en suelos volcánicos chilenos. Agricultura Técnica 43: 239-248.

Borie, F. \& J. M. B ARea. 1985. Occurrence of lipid-P in volcanic ash derived soils of Chile. Agrochimica 28: 317-324.

Borie, F., H. Zunino \& L. Martínez. 1989. Macromolecule P-associations and inositol phosphates in some Chilean volcanic soils of temperate regions. Communications in Soil Science and Plant Analysis 20: 1881-1894.

Borie, F., R. Rubio, E. Moraga \& A. Morales. 1996. Roca fosfórica y la doble simbiosis de hongos micorrizógenos-VA y Rhizobium trifolii en trébol rosado. Agricultura Técnica 56: 237 243.

Borie, F., R. Rubio \& C. Schalchli. 1998. Micorrizas arbusculares y actividad fosfatásica de diez cultivares de trigo. Agricultura Técnica 58: 4755.

Borie, F. \& R. Rubio. 1999. Effects of arbuscular mycorrhizae and liming on growth and mineral acqquisition of aluminum-tolerant and aluminum-sensitive barley cultivars. Journal of Plant Nutrition 22: 121-137.

Borie, F., Y. Redel, R. Rubio, J. L. Rouant \& J. M. BAREA. 2002. Interactions between crop 
P in Chilean volcanic soils: Borie, E. \& R. Rubio

residues application and mycorrhizal developments and some soil-root interface properties and mineral acquisition by plants in acidic soil. Biology and Fertility of Soils 36: 87-92.

Briceño, M. A. 2001. Efectos de la adición de lodo sobre la selectividad catiónica ( $\mathrm{K} \mathrm{Ca}$ ) y distribución de $\mathrm{P}$ en suelos volcánicos chilenos. Tesis Doctoral en Química, Universidad de Santiago de Chile, Chile.

Briceño, M. A., M. Escudey M. D. Borchardt \& A. C. Chang. 2003. Characterization of chemical $\mathrm{P}$ forms in volcanic soils using ${ }^{31} \mathrm{P}-\mathrm{NMR}$ spectros-copy. Communications in Soil Science and Plant Analysis (in press).

CHANG, S. C. \& M. L. JACKsON. 1957. Fractionation of soil phosphorus. Soil Science 84: 133-144.

Condron, L. M., K. M. Goh \& R. H. Newman. 1985. Nature and distribution of soil phosphorus as released by a sequential extraction method followed by ${ }^{31} \mathrm{P}$ nuclear magnetic resonance analysis. Journal of Soil Science 36: 199-207.

Dalal R. C. 1977. Soil organic phosphorus. Advances in Agronomy 29: 83-117.

Dick, W. A. \& M. A. Tabatabai. 1977. An alkaline oxidation method for determination of total phosphorus in soils. Soil Science Society of America Journal 41: 511-514.

Escudey, M., G. Galindo, J. E. Foerster, I. Salazar, A. L. Page \& A. Chang. 1997. ${ }^{31}$ PhosphorusNuclear Magnetic Resonance analysis in extracts of a phosphorus enriched volcanic soil of Chile. Communications in Soil Science and Plant Analysis 28: 727-737.

Escudey, M., G. Galindo, J. E. Foerster, M. A. Briceño, P. Díaz \& A. C. Chang. 2001. Chemical forms of phosphorus of volcanic ash derived soils in Chile. Communications in Soil Science and Plant Analysis 32: 601-616.

George, T. S., P. J. Gregory, M. Wood, D. Read \& R. J. Buresh. 2002. Phosphatase activity and organic acids in the rhizosphere of potential agroforestry species and maize. Soil Biology and Biochemistry 34: 1487-1494.

Hedley, M.J., J.W.B. Stewart \& B. S. Chauhan. 1982. Changes in inorganic and organic soil phosphorus fractions induced by cultivation practices and by laboratory incubations. Soil Science Society of America Journal 46: 970-976.

Hinedi, Z. R., A. C. Chang \& R. W. K. Lee. 1988. Mineralization of phosphorus in sludge-amended soils monitored by phosphorus 31 Nuclear Magnetic Resonance Spectroscopy. Soil Science Society of America Journal 52: 15931596.

Hinedi, Z. R., A. C. Chang \& J. P. Yesinowski. 1989. Characterization of phosphorus in sludge extracts using phosphorus 31 Nuclear Magnetic Resonance Spectroscopy. Soil Science Society of America Journal 53: 1053-1056.

Irving, G. C. J \& D. J. Cosgrove. 1982. The use of gas liquid chromatography to determine the proportions of inositol isomers present as pentakis-and hexakisphosphates in alkaline extracts of soils. Communications in Soil Science and Plant Analysis 13: 957-967.

Landeweert, R., E. Hoffland, R. Finlay, T. Kuyper \& N. V AN BREMEN. 2001. Linking plants to rocks: ectomycorrhizal fungi movilize nutrients from minerals. Trends in Ecology and Evolution 16: 248-254.

Parfitt, R. L. 1980. Chemical properties of variable charge soils. In: Soils with variable charge (ed. B.K.G. Theng ), pp 167-194. New Zealand Soil Bureau, Lower Hutt, N.Z.

Peirano, P., S. M. A guilera, G. Borie \& M. Caiozzi. 1992. Actividad biológica en suelos volcánicos y su relación con la dinámica de la materia orgánica. Agricultura Técnica 52: 367371.

Pinochet, D., G. Epple \& R. Macdonald. 2001. Fracciones de fósforo orgánico en un transecto de suelos de origen volcánico y metamórfico. Revista de la Ciencia del Suelo y Nutrición Vegetal 1: 58-69.

Robinson, J. S., C. T. Lohnston \& K. R. Reddy. 1998. Combined chemical and ${ }^{31} \mathrm{P}-\mathrm{NMR}$ spectroscopic analysis of phosphorus in wetland organic soils. Soil Science 163: 705713.

Stevenson, F. J. \& M. A. Cole. 1999. Cycles of soil. Second Edition. John Wiley \& Sons, London. 428 pp.

Stewart, J. H. \& J. M. Oades. 1972. The determination of organic phosphorus in soils. Journal of Soil Science 23: 38-49.

Thomas, S. M., A. H. Johnson, J. Frizano, D. R.Vann, D. J. Zarin \& A. Joshi. 1999. Phosphorus fractions in montane forest soils of the Cordillera de Piuché, Chile: Biogeochemical implications. Plant and Soil 211:139-148.

Tiessen, H. \& J. O. Moir. 1993. Characterization of available $\mathrm{P}$ by sequential extraction. In: Soil sampling and methods of analysis (ed M.R. Carter), pp. 75-86. Boca Raton, Florida, USA.

Vance, G. F, F. J. Stevenson \& F. J. Sikora. 1996. Naturally occurring aluminum-organic complexes. In: The environmental chemistry of Aluminum, $2^{\text {nd }}$ Ed. (ed G. Sposito), pp 169220. CRC Press, Boca Raton, Florida, USA.

Zhang, T. Q., A. F. Machenzie \& F. Sauriol. 1999. Nature of soil organic phosphorus as affected by long-term fertilization under continuous corn (Zea mays L): AP-31 NMR study. Soil Science 164: 662-670.

Zunino, H., F. Borie, M. Aguilera, J.P. Martin \& K. HAIDER. 1982a. Decomposition of 14C-labeled glucose, plant and microbial products and phenols in volcanic ash-derived soils of Chile. Soil Biology and Biochemistry 14: 37-43.

Zunino, H., P. Peirano, M. Caiozzi \& J.P. Martin. 
Gayana Bot. 60(1), 2003

1982b. Decomposition of 14C-labeled lignins, model humic acid polymers, and fungal melanins in allophanic soils. Soil Biology and Biochemistry 14: 289-293.

Zunino, H., M. Aguilera, P. Peirano, M. Caiozzi \&
A. Rex. 1982c. Bioquímica de suelos derivados de cenizas volcánicas. III. Síntesis microbiana de polímeros húmicos y su capacidad de adsorción de $\mathrm{Zn}$ (II) y $\mathrm{Mg}$ (II). Agricultura Técnica 42: 287-292.

Received: $16 / 12 / 02$

Accepted: 05/05/03 